\title{
STATUS KEWARGANEGARAAN GANDA DILIHAT DARI PERSPEKTIF UNDANG-UNDANG NOMOR 12 TAHUN 2006 TENTANG KEWARGANEGARAAN REPUBLIK INDONESIA
}

\author{
Glery Lazuardi \\ Mahasiswa Program Magister Ilmu Hukum, Pascasarjana Universitas Jayabaya, Jakarta \\ Email Korespondensi: glerylazuardi@gmail.com
}

\begin{abstract}
This study aims to analyze the status of dual citizenship in terms of Law Number 12 of 2006 on Citizenship of the Republic of Indonesia. This research uses normative legal research methods. Normative legal research is research conducted by conducting a study of statutory regulations, namely Law Number 12 of 2006 on Citizenship of the Republic of Indonesia, whether it is relevant to be applied to a legal problem. The legal problem in this study is the citizenship status of Gloria Natapradja. In 2016, Gloria Natapradja was dismissed as an official of the Heirloom Flag raiser after having French citizenship, who followed the citizenship of her biological father. After conducting research, it is known, the state has an obligation to protect the rights of citizens. The state should pay attention and protect citizens regarding the status of citizens. The problems experienced by Gloria Natapradja, because citizenship status can be seen as not yet the maximum role of the government to protect citizens. The issue of citizenship in Gloria Natapradja requires the government to review the regulation of citizenship status as regulated in Law Number 12 of 2006 on Citizenship of the Republic of Indonesia.
\end{abstract}

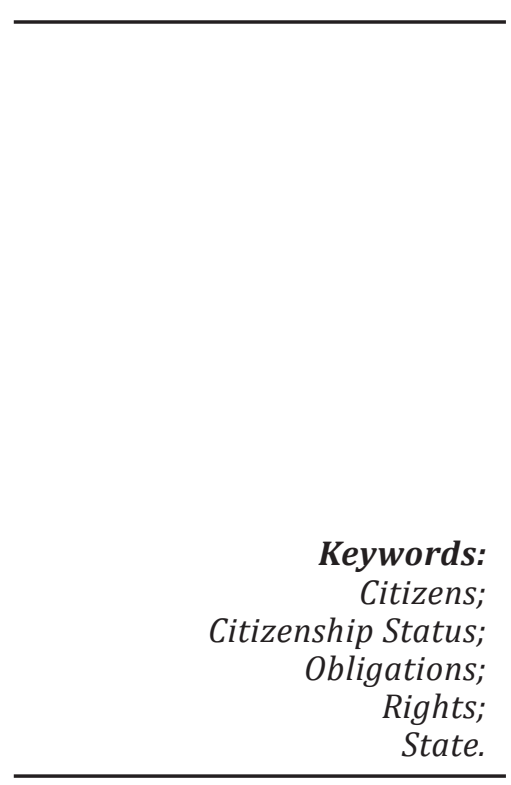

artikel dengan akses terbuka dibawah lisensi CC BY -4.0

\section{PENDAHULUAN}

Undang-Undang Dasar Negara Republik Indonesia Tahun 1945 (selanjutnya disebut UUD NRI Tahun 1945) sebagai konstitusi Negara Kesatuan Republik Indonesia mengatur warga negara dan penduduk. Berdasarkan Pasal 26 ayat (1) UUD NRI Tahun 1945 mengatur bahwa:

"Yang menjadi warga negara ialah orang-orang bangsa Indonesia asli dan orang-orang bangsa lain yang disahkan dengan Undang-Undang sebagai warga negara.

Pada UUD NRI Tahun 1945, warga negara tidak hanya diatur sebatas definisi atau pengertian, tetapi juga menyangkut hak dan kewajiban. Warga negara dan negara mempunyai hubungan timbal balik dari status kewarganegaraan yang melekat di 
warga negara. Hubungan timbal balik itu berupa kewajiban negara memberikan perlindungan kepada warga negara. Begitu juga sebaliknya, di mana, warga negara mempunyai hak dan kewajiban terhadap negara. ${ }^{1}$

Ketentuan mengenai kewarganegaraan diatur dalam Undang-Undang Republik Indonesia Nomor 12 Tahun 2006 tentang Kewarganegaraan Republik Indonesia (selanjutnya disebut UU No. 12 Tahun 2006). Negara Indonesia menganut prinsip kewarganegaraan ganda terbatas. UU No. 12 Tahun 2006 memberikan kewarganegaraan ganda terbatas kepada anak-anak hasil perkawinan campuran sampai berusia 18 tahun atau sudah menikah. Setelah itu, seseorang dapat memilih salah satu warga negara untuk menjadi kewarganegaraannya. Selama memiliki kewarganegaraan ganda terbatas, anak hasil perkawinan campuran tunduk kepada dua yurisdiksi kewarganegaraan orang tua. ${ }^{2}$

Berdasarkan ketentuan di atas, Indonesia tidak mengenal kewarganegaraan ganda atau bipatride dan tanpa kewarganegaraan atau apatride. UU No. 12 Tahun 2006 mengatur status kewarganegaraan. Status kewarganegaraan itu tidak hanya sekedar ketentuan, tetapi mempunyai kekuatan mengikat berupa status hukum yang memberikan hak dan perlindungan warga negara sebagaimana diatur di berbagai peraturan perundangundangan.

Negara Indonesia menjadi sorotan ketika orang keturunan Indonesia menghadapi permasalahan status warga negara. Gloria Natapradja Hamel digugurkan dari Pasukan Pengibar Bendera Pusaka (Paskibraka). Diketahui, Gloria mempunyai paspor Negara Prancis Nomor 12AA66042 yang berlaku sejak 20 Februari 2014-19 Februari 2018. Gloria mempunyai paspor Prancis, karena orang tuanya melakukan pernikahan campuran. Ibu Gloria berstatus Warga Negara Indonesia dan ayah Gloria berstatus Warga Negara Prancis. Direktorat Jenderal Administrasi Hukum Umum mengeluarkan surat AHU.4.AH.10.01-123 tertanggal 15 Agustus 2016 yang ditandatangani Direktur Jenderal Administrasi Hukum Umum Direktur Tata Negara Tehna Bana Sitepu. Konsekuensi dari diterbitkan surat itu adalah Gloria tidak diperbolehkan terlibat di Paskibraka yang mengibarkan bendera merah-putih di Istana Merdeka. ${ }^{3}$

Melihat dari permasalahan yang dialami Gloria Natapradja, itu terjadi karena tidak ada perhatian dan perlindungan dari pemerintah mengenai status warga negara. Pemerintah bertanggungjawab terhadap pemenuhan hak dan perlindungan setiap warga negara. Persoalan kewarganegaraan ganda tampaknya masih senantiasa diperdebatkan di kalangan para akademisi dan ahli, karena banyak memunculkan persoalan sehingga penting untuk diteliti.

${ }^{1}$ Laili Fadliyah. (2018). "Analisis Putusan Mahkamah Konstitusi Nomor 80/PUU-XIV/2016 tentang Uji Materi Pasal 41 Undang-Undang Nomor 12 Tahun 2006 tentang Kewarganegaraan”. Skripsi. Fakultas Syari'ah dan Hukum, Universitas Islam Negeri Sunan Kalijaga, Yogyakarta, hlm 5.

${ }^{2}$ Leonora Bakarbessy \& Sri Handajani. (2012). Kewarganegaraan Ganda Anak dalam Perkawinan Campuran dan Implikasinya dalam Hukum Perdata Internasional. Perspektif: Kajian Masalah Hukum dan Pembangunan, Universitas Wijaya Kusuma Surabaya, 17(1), hlm 2.

${ }^{3}$ Ady Anugrahadi. (2016, 16 Agustus). 6 Kisah Gloria, Paskibraka yang Gagal Kibarkan Bendera di Istana. Dalam Liputan6.com. Diakses pada tanggal 23 Juli 2020. 
Untuk itu, di dalam tulisan ini akan dijabarkan serta dianalisa bagaimana status kewarganegaraan ganda ditinjau dari UU No. 12 Tahun 2006. Tujuan penelitian ini untuk mengetahui bagaimana kedudukan status kewarganegaraan dan mengetahui apakah konsep kewarganegaraan ganda dalam UU No. 12 Tahun 2006 masih relevan diterapkan di Indonesia. Peneliti berharap penelitian ini bermanfaat bagi pengembangan teori hukum maupun bahan kajian kewarganegaraan pada masa mendatang. Bagi pemerintah, penelitian ini bermanfaat membuat kebijakan di bidang kewarganegaraan. Sedangkan bagi masyarakat, memahami pentingnya status kewarganegaraan bagi seorang warga negara.

\section{METODE}

Peneliti melakukan penelitian hukum normatif. Penelitian hukum normatif dilakukan dengan cara melakukan kajian terhadap undang-undang. ${ }^{4}$ UU No. 12 Tahun 2006 merupakan objek yang menjadi kajian di dalam penelitian ini. UU No. 12 Tahun 2006 menjadi fokus sentral penelitian. Di penelitian ini, peneliti menggunakan bahan hukum primer yang terdiri dari peraturan perundang-undangan dan bahan hukum sekunder berupa materi berkaitan permasalahan dari bahan hukum primer yang terdiri dari buku-buku dan jurnal terkait status kewarganegaraan ganda. Peneliti melakukan studi kepustakaan untuk menginventarisasi dan mengidentifikasi peraturan perundangundangan, serta klasifikasi dan sistematisasi bahan hukum sesuai permasalahan penelitian. Selama melakukan studi kepustakaan, peneliti melakukan proses membaca dan mencatat bahan-bahan pustaka yang terkait objek penelitian. Peneliti menganalisa data penelitian hukum normatif. Proses analisa data dilakukan dengan cara menganalisa secara deskriptif kualitatif.

\section{HASIL DAN PEMBAHASAN}

\section{A. Negara dan Warga Negara}

Negara diterjemahkan dari bahasa asing, yaitu etat (Prancis), state (Inggris), steat (Belanda dan Jerman). Sejumlah pakar mencoba mendefinisikan kata negara. Miriam Budiardjo, pakar ilmu politik, merangkum pengertian dari istilah negara menurut beberapa ahli, antara lain yaitu: ${ }^{5}$

1. Roger F. Soltau mengartikan bahwa "Negara adalah alat yang mengendalikan persoalan bersama atas nama masyarakat";

2. Harold J. Lasky mengartikan bahwa "Negara adalah suatu masyarakat yang diintegrasikan, karena mempunyai wewenang yang bersifat memaksa dan yang secara sah"; dan

${ }^{4}$ Sarah Sarmila Begem, Nurul Qamar, \& Hamza Baharuddin. (2019). Sistem Hukum Penyelesaian Pelanggaran Hak Asasi Manusia (HAM) Berat Melalui Mahkamah Pidana Internasional. SIGn Jurnal Hukum, CV. Social Politic Genius (SIGn), 1(1), hlm. 3.

${ }^{5}$ Miriam Budiardjo. (2002). Dasar-Dasar Ilmu Politik (Edisi Revisi). Jakarta: PT. Gramedia Pustaka Utama, hlm39-40. 
3. Robert M. Maclever mengartikan bahwa "Negara adalah asosiasi yang menyelenggarakan penertiban dalam suatu wilayah dengan berdasarkan sistem hukum yang diselenggarakan oleh suatu pemerintah yang untuk maksud tersebut diberikan kekuasaan memaksa".

Konvensi Montevidio pada 1993 menyatakan negara dapat dikatakan sebagai subjek hukum internasional apabila telah mempunyai unsur-unsur, yaitu penduduk yang tetap, wilayah tertentu, pemerintah, dan kemampuan mengadakan hubungan dengan negara-negara lainnya. Melihat unsur-unsur negara, maka Indonesia masuk dalam kategori suatu negara. Negara Indonesia berdiri pada 17 Agustus 1945 pada saat Soekarno dan Hatta membacakan proklamasi kemerdekaan. Pembacaan proklamasi itu menandakan berdirinya Negara Indonesia secara de facto. Sementara itu, secara de jure, Negara Indonesia berdiri pada 18 Agustus 1945 atau pada saat UUD NRI Tahun 1945 lahir.

Oleh para pendiri bangsa, Indonesia dicita-citakan sebagai suatu negara hukum. Melihat Indonesia sebagai negara hukum, maka konsep Negara Hukum, yang harus dijadikan panglima dalam dinamika kehidupan kenegaraan adalah hukum, bukan politik ataupun ekonomi. ${ }^{6}$ Penerapan prinsip negara hukum Indonesia berpedoman pada unsur-unsur negara hukum secara umum, yaitu upaya perlindungan terhadap hak asasi manusia, pemisahan atau pembagian kekuasaan, pelaksanaan kedaulatan rakyat, penyelenggaraan pemerintahan yang didasarkan pada peraturan perundang-undangan yang berlaku dan adanya peradilan administrasi negara. ${ }^{7}$

UUD NRI Tahun 1945 sebagai konstitusi Negara Republik Indonesia mengatur Wilayah Negara, Warga Negara, dan Penduduk serta Hak Asasi Manusia. Isu pokok yang menjadi pedoman perkembangan prinsip-prinsip negara hukum, yaitu masalah pembatasan kekuasaan dan perlindungan hak asasi manusia. Kepentingan paling mendasar dari setiap warga negara adalah perlindungan terhadap hak-hak sebagai manusia. ${ }^{8}$

Jaminan perlindungan dan pemenuhan hak warga negara dalam konstitusi telah dicantumkan di UUD NRI Tahun 1945. Sejumlah pasal di UUD NRI Tahun 1945 mengatur mengenai hak warga negara dan kewajiban negara. Pemerintah perlu membuat kebijakan untuk mengimplementasikan ketentuan berdasarkan UUD NRI Tahun 1945. ${ }^{9}$

\footnotetext{
${ }^{6}$ Jimly Asshiddiqie. (2011, 22-24 November). Gagasan Negara Hukum Indonesia. Makalah dipresentasikan pada Forum Dialog Perencanaan Pembangunan Hukum Nasional, diselenggarakan oleh Badan Pembinaan Hukum Nasional, Kementerian Hukum dan Hak Asasi Manusia Republik Indonesia, di Jakarta.

${ }^{7}$ Haposan Siallagan. (2016). Penerapan Prinsip Negara Hukum di Indonesia. Sosiohumaniora: Jurnal Ilmu-Ilmu Sosial dan Humaniora, Universitas Padjadjaran, 18(2), hlm. 137.

${ }^{8}$ Achmad Edi Subiyanto. (2011). Perlindungan Hak Konstitusional Melalui Pengaduan Konstitusional. Jurnal Konstitusi, Mahkamah Konstitusi RI, 8(5), hlm. 708.

${ }^{9}$ Andi Muhammad Asrun. (2016). Hak Asasi Manusia Dalam Kerangka Negara Hukum: Catatan Perjuangan di Mahkamah Konstitusi. Jurnal Cita Hukum, UIN Syarif Hidayatullah Jakarta, 4(1), hlm. 137.
} 


\section{B. Pengaturan Status Kewarganegaraan di Indonesia}

Status kewarganegaraan ditentukan berdasarkan kesepakatan di dalam suatu negara. Ketentuan itu menjadi pedoman menentukan status kewarganegaraan. ${ }^{10}$ Penentuan status kewarganegaraan didasarkan pada kewarganegaraan yang diperoleh seseorang. Kewarganegaraan seseorang diperoleh berdasarkan tempat kelahiran atau Ius Soli dan kewarganegaraan yang diperoleh berdasarkan hubungan darah atau Ius Sanguinis. ${ }^{11}$

Perbedaan asas Ius Soli dan IUs Sanguinis mengakibatkan munculnya kewarganegaraan ganda. Sejumlah negara, seperti Amerika Serikat, Australia, Kanada, Selandia Baru, Swiss, Turki, Jamaika menganut kewarganegaraan ganda. Sampai saat ini, setidaknya terdapat 44 negara yang menerapkan kewarganegaraan ganda. Kewarganegaraan ganda lahir karena negara-negara itu memiliki persyaratan kewarganegaraan berbeda.

Status kewarganegaraan bagi individu adalah suatu hal yang sangat penting. Warga negara merupakan salah satu unsur atau syarat berdirinya negara. Negara dan warga negara mempunyai hubungan timbal balik. Individu yang menjadi warga negara wajib mematuhi segala ketentuan hukum yang dibuat negara dan negara wajib melindungi warga negara di mana pun berada. ${ }^{12}$

Namun pada kenyataannya, di suatu negara terdapat seorang tidak mempunyai status kewarganegaraan atau apatride dan mempunyai lebih dari dua kewarganegaraan atau multipatride. Konvensi 1954 mengenai Status OrangOrang Tanpa Kewarganegaraan mendefinisikan orang tanpa kewarganegaraan sebagai orang yang tidak dianggap sebagai warga negara oleh negara manapun di bawah yurisdiksi hukum. Belakangan ini terjadi peningkatan populasi orang tanpa kewarganegaraan atau berpotensi berisiko tanpa kewarganegaraan. Salah satu negara yang mengalami peningkatan populasi orang tanpa kewarganegaraan tersebut, yaitu Amerika Serikat. ${ }^{13}$

Politik hukum kewarganegaraan Indonesia menganut prinsip berkewarganegaraan tunggal. Prinsip kewarganegaraan tunggal sudah dianut sejak kemerdekaan Negara Republik Indonesia. Adapun beberapa peraturan tentang kewarganegaraan di Indonesia antara lain sebagai berikut:

1. Undang-Undang Republik Indonesia Nomor 3 Tahun 1946 tentang Warga Negara dan Penduduk Negara;

\footnotetext{
${ }^{10}$ W. Wahono \& Abdul Atsar. (2019). Buku Ajar Pendidikan Pancasila dan Kewarganegaraan. Yogyakarta: Deepublish, hlm. 44.

${ }^{11}$ Sali Kadria. (2017). A Historical View about Concepts, Theories and Types of Nationalism. Anglisticum, Association-Institute for English Language and American Studies, 6(6), hlm. 25.

${ }^{12}$ Rahmawati Novia Sigit. (2020). Perlindungan Terhadap Orang Tanpa Kewarganegaraan (Stateless People) dalam Hukum Internasional (Studi Kasus Etnis Rohingya di Myanmar). Uti Possidetis, Universitas Jambi, 1(1), hlm. 113.

${ }^{13}$ Donald Kerwin, et al. (2020). Statelessness in the United States: A Study to Estimate and Profile the US Stateless Population. Journal on Migration and Human Security, SAGE journals, 8(2), hlm. 151.
} 
2. Undang-Undang Republik Indonesia Nomor 6 Tahun 1947 tentang Perubahan Undang-Undang Nomor 3 Tahun 1946 tentang Warga Negara dan Penduduk Negara;

3. Undang-Undang Republik Indonesia Nomor 62 Tahun 1958 tentang Kewarganegaraan Republik Indonesia;

4 Undang-Undang Republik Indonesia Nomor 3 Tahun 1976 tentang Perubahan Pasal 18 Undang-Undang Nomor 62 Tahun 1958 tentang Kewarganegaraan Republik Indonesia;

5. Undang-Undang Republik Indonesia Nomor 12 Tahun 2006 tentang Kewarganegaraan Republik Indonesia; serta

6. Peraturan Pemerintah Republik Indonesia Nomor 2 Tahun 2007 tentang Tata Cara Memperoleh, Kehilangan, Pembatalan, dan Memperoleh Kembali Kewarganegaraan Republik Indonesia.

Sistem kewarganegaraan tunggal diterapkan untuk mengantisipasi kewarganegaraan ganda dan tanpa kewarganegaraan. Prinsip asas kewarganegaraan tunggal yang dijelaskan pada penjelasan umum UU No. 12 Tahun 2006 membuat tidak ada ruang bagi orang berkewarganegaraan ganda dan tanpa kewarganegaraan. ${ }^{14}$

Negara Indonesia menerapkan prinsip Ius Soli dan Ius Sanguinis secara terbatas. Prinsip Ius Soli mendefinisikan semua orang yang lahir di Indonesia adalah Warga Negara Indonesia. Sedangkan, prinsip Ius Sanguinis mendefinisikan semua orang yang lahir dari keturunan Warga Negara Indonesia di luar negeri adalah Warga Negara Indonesia. UU No. 12 Tahun 2006 mengakomodasi penerapan status kewarganegaraan ganda secara terbatas bagi anak yang lahir dari perkawinan campuran. ${ }^{15}$

Pembentuk undang-undang mengatur status kewarganegaraan ganda secara terbatas untuk mengatasi permasalahan yang ditimbulkan dari perkawinan campuran. Permasalahan itu dapatterjadi selama perkawinan berlangsung ataupun setelah berakhirnya perkawinan. Kewarganegaraan ganda terbatas menimbulkan konsekuensi pada anak hasil perkawinan campuran, di mana anak diharuskan tunduk pada dua yurisdiksi dari orang tua yang berbeda kewarganegaraan. ${ }^{16}$

Status kewarganegaraan ganda diatur di sejumlah pasal dalam UU No. 12 Tahun 2006, meliputi Pasal 4, Pasal 5 ayat (1), Pasal 6 ayat (1), ayat (2), dan ayat (3), Pasal 21 ayat (1), Pasal 23 huruf c, Pasal 25 ayat (1), Pasal 25 ayat (2), Pasal 25 ayat (3), dan Pasal 25 ayat (4), serta Pasal 41.

\footnotetext{
${ }^{14}$ Chelsea Chesy Bernanda. (2020). Pemberian Kewarganegaraan Indonesia terhadap Archandra Tahar Ditinjau dari Undang-Undang Nomor 12 Tahun 2006 tentang Kewarganegaraan Republik Indonesia. Al Qodiri: Jurnal Pendidikan, Sosial dan Keagamaan, Universitas Surabaya, 18(1), hlm. 204.

${ }^{15}$ May Lim Charity. (2016). Urgensi Pengaturan Kewarganegaraan Ganda bagi Diaspora Indonesia. Jurnal Konstitusi, Mahkamah Konstitusi RI, 13(4), hlm. 816.

${ }^{16}$ Eka Martiana Wulansari. (2015). Konsep Kewarganegaraan Ganda Tidak Terbatas (Dual Nasionality) dalam Sistem Kewarganegaraan di Indonesia. Rechts Vinding Online, Kementerian Hukum dan Hak Azasi Manusia RI, hlm. 1.
} 
Jika merujuk pada ketentuan di atas, Negara Indonesia mengakui adanya asas kewarganegaraan ganda yang terbatas untuk anak. Anak memiliki kewarganegaraan ganda atau dwi kewarganegaraan sampai batas umur yang ditentukan, yaitu 18 tahun atau sampai anak tersebut menikah. Kebijakan ini dikeluarkan karena peraturan sebelumnya tidak tercermin hak asasi manusia untuk anak dari hasil perkawinan campuran sehingga mencederai hak asasi anak tersebut. Dengan adanya Undang-Undang Kewarganegaraan baru ini diharapkan tidak ada lagi anak dari hasil perkawinan campuran yang tidak memiliki kewarganegaraan.

Namun, dalam pelaksanaan penerapan status kewarganegaraan ganda dalam UU No. 12 Tahun 2006 menimbulkan permasalahan. Permasalahan terjadi, karena ketentuan tersebut tidak memberikan status kewarganegaraan Indonesia secara otomatis bagi wanita Warga Negara Asing yang menikah dengan pria Warga Negara Indonesia, begitu juga sebaliknya. Hal ini mengakibatkan perbedaan kewarganegaraan dalam keluarga suatu perkawinan campuran. Faktor perbedaan kewarganegaraan diantara para pihak yang membedakan suatu perkawinan campuran dengan perkawinan tidak campuran. Perbedaan kewarganegaraan tidak saja terjadi saat awal dimulainya suatu perkawinan campuran, tetapi dapat berlanjut setelah terbentuknya suatu keluarga perkawinan campuran. ${ }^{17}$

Memilih kewarganegaraan merupakan hak asasi manusia. Sehingga, siapapun termasuk negara tidak dapat memaksakan kehendak kepada seseorang menentukan kewarganegaraan. Perkawinan campuran yang berbeda kewarganegaraan merupakan dampak dari interaksi antar umat manusia di dunia. Perkawinan campuran tidak dapat dilarang, karena ini merupakan hak asasi manusia untuk memilih seseorang menjadi pasangan hidup. Perkawinan campuran berdampak hukum pada status kewarganegaraan suami dan istri serta anak yang hadir dari hasil perkawinan tersebut. Atas dasar itu, negara tidak boleh menggunakan instrumen undang-undang memaksa seorang anak memilih ikut kewarganegaraan ayah atau ibu, Negara hanya berkepentingan seseorang memenuhi kewajiban sebagai warga negara. Negara bertanggungjawab melindungi warga negara, sebagaimana berdasarkan Pasal 28 D ayat (4) UUD NRI Tahun 1945 mengatur bahwa "setiap orang berhak atas status kewarganegaraan". Pada ketentuan itu, tidak dijelaskan seseorang berhak atas satu atau dua status kewarganegaraan. Hanya mengatur seorang warga negara harus mempunyai kewarganegaraan dan tidak berstatus tidak mempunyai kewarganegaraan. Untuk memberikan perlindungan hukum kepada setiap warga negara dan memberikan jaminan kepastian hukum tentang siapa saja Warga Negara Indonesia itu sehingga tercermin adanya persamaan hukum di antara warga negara. Di sejumlah negara, ada yang melegalkan seseorang memiliki kewarganegaraan ganda ada juga yang melarang adanya kewarganegaraan ganda.

${ }^{17}$ Achmadudin Rajab. (2017). Peran Perubahan Undang-Undang Kewarganegaraan dalam Mengakomodir Diaspora untuk Peningkatan Kesejahteraan Masyarakat. Jurnal Konstitusi, Mahkamah Konstitusi RI, 14(3), hlm. 541. 


\section{Analisa Status Kewarganegaraan Gloria Natapradja}

Pada Agustus 2016, Indonesia menghadapi permasalahan terkait status kewarganegaraan. Status kewarganegaraan ganda yang terjadi pada Gloria Natapradja Hamel menjadi perbincangan sehingga menimbulkan pro dan kontra. Gloria Natapradja lahir dari pasangan suami-istri yang melakukan perkawinan campuran. Gloria lahir di DKI Jakarta pada 1 Januari 2020. Ayah Gloria, Didier Andre Aguste Hamel, Warga Negara Prancis dan ibu Gloria, Ira Hartini, Warga Negara Indonesia. Tercatat, Gloria memegang paspor berkewarganegaraan Prancis nomor 14AA66042 yang berlaku sejak 20 Februari 2014 sampai 19 Februari 2019 dan pemegang KITAP Nomor 2D21JE0099-Q, yang berlaku sampai 18 Juli 2021.

Permasalahan kewarganegaraan Gloria itu muncul setelah siswi SMA Islam Dian Didaktika, Depok itu tidak diperbolehkan bertugas sebagai anggota Pasukan Pengibar Bendera Pusaka pada hari kemerdekaan Republik Indonesia di Istana Negara pada 17 Agustus 2016. Kementerian Hukum dan Hak Asasi Manusia mengeluarkan suratyang menyebut Gloria Warga Negara Prancis, karena memegang paspor dari negara tersebut. Status kewarganegaraan Gloria sebagai Warga Negara Prancis dipertegas melalui surat Direktorat Jenderal Administrasi Hukum Umum Kementerian Hukum dan Hak Asasi Manusia bernomor AHU.4.AH.10.01-123 bertanggal 15 Agustus 2016 perihal permohonan status kewarganegaraan atas nama Gloria Natapradja Hamel. Surat itu ditandatangani Dirjen Administrasi Hukum Umum Direktur Tata Negara, Tehna Bana Sitepu dengan tembusan Dirjen Administrasi Hukum Umum dan Direktur Izin Tinggal Keimigrasian.

Gloria memegang paspor berkewarganegaraan Prancis, karena negara itu membuka peluang bagi anak yang lahir dari salah satu orang tua berkewarganegaraan Prancis untuk menjadi warga negara. Bagi anak yang lahir di luar Prancis, yang memiliki setidaknya satu orangtua yang merupakan Warga Negara Prancis adalah keturunan Prancis. Untuk seseorang yang ingin berkewarganegaraan Prancis cukup menikah selama satu tahun dengan Warga Negara Prancis. Tidak ada persyaratan tempat tinggal bagi pasangan perkawinan campuran untuk memperoleh kewarganegaraan Prancis. Prancis memperbolehkan warga negara untuk memiliki kewarganegaraan ganda.

Mempunyai paspor Prancis menimbulkan konsekuensi Gloria sudah menjadi Warga Negara Prancis, dimana berdasarkan Pasal 1 angka 16 Undang-Undang Republik Indonesia Nomor 6 Tahun 2011 tentang Keimigrasian menjelaskan bahwa:

"Paspor Republik Indonesia yang selanjutnya disebut Paspor adalah dokumen yang dikeluarkan oleh Pemerintah Republik Indonesia kepada warga negara Indonesia untuk melakukan perjalanan antarnegara yang berlaku selama jangka waktu tertentu." 
Selanjutnya, berdasarkan Pasal 23 huruf h UU No. 12 Tahun 2006 mengatur bahwa:

"Warga Negara Indonesia kehilangan kewarganegaraannya jika yang bersangkutan mempunyai paspor atau surat yang bersifat paspor dari negara asing atau surat yang dapat diartikan sebagai tanda kewarganegaraan yang masih berlaku dari negara lain atas namanya."

Gloria mengikuti kewarganegaraan ayahnya karena lahir pada tahun 2000. Dia tunduk pada UU No. 62 Tahun 1958. Namun, dengan hadirnya UU No. 12 Tahun 2006 membuat Negara Indonesia menganut kewarganegaraan ganda terbatas, dimana berdasarkan Pasal 41 UU No. 12 Tahun 2006 mengatur bahwa:

"Anak yang lahir ... dan anak yang diakui atau diangkat secara sah ... dan belum berusia 18 (delapan belas) tahun atau belum kawin memperoleh Kewarganegaraan Republik Indonesia berdasarkan Undang-Undang ini dengan mendaftarkan diri kepada Menteri melalui Pejabat atau Perwakilan Republik Indonesia paling lambat 4 (empat) tahun setelah Undang-Undang ini diundangkan."

Namun, Gloria tidakmendaftarkan diripalinglambat4tahun setelahundang-undang ini diundangkan. Sehingga, dia tidak tercatat sebagai Warga Negara Indonesia dan hanya diakui sebagai Warga Negara Prancis mengikuti kewarganegaraan ayahnya. Melihat hal ini, seharusnya, pemerintah mempermudah syarat memperoleh kewarganegaraan bagi mereka yang mempunyai garis keturunan darah. Syarat itu berupa anak dari hasil perkawinan campuran berhak mendapatkan status kewarganegaraan Indonesia secara otomatis tanpa orang tua melakukan pendaftaran anak kepada instansi terkait. Selain anak, status kewarganegaraan ganda dapat ditetapkan kepada mereka yang melakukan perkawinan campuran. Perkawinan campuran merupakan konsekuensi dari hubungan interaksi antara Warga Negara Indonesia (WNI) dengan Warga Negara Asing. Pemerintah dapat mengawasi semua Warga Negara Indonesia termasuk mereka yang mempunyai kewarganegaraan ganda.

\section{KESIMPULAN DAN SARAN}

Berdasarkan penelitian, persoalan Gloria Natapradja mengenai kewarganegaraan ganda merupakan dampak dari kurang perhatiannya pemerintah Indonesia melindungi Warga Negara Indonesia (WNI) termasuk pemberian status kewarganegaraan. Pemerintah harus melakukan perubahan terhadap UU No. 12 Tahun 2006. UU No. 12 Tahun 2006 mempunyai kelemahan, karena tidak memberikan status kewarganegaraan Indonesia secara otomatis bagi mereka yang melakukan perkawinan campuran. Sehingga, mengakibatkan perbedaan kewarganegaraan yang berdampak pada yurisdiksi anak dalam keluarga suatu perkawinan campuran. Untuk itu, pemerintah harus memperhatikan status kewarganegaraan bagi warga negara yang tinggal di Indonesia, sehingga pada kemudian hari tidak menimbulkan masalah hukum. Melihat persoalan yang terjadi pada Gloria Natapradja Hamel, maka pemerintah perlu mengkaji berlakunya UU No. 12 Tahun 2006. Demi keadilan hukum anak-anak yang 
lahir di negara menganut asas Ius Soli dari kedua orang tua warga negara Indonesia (WNI) berhak mendapatkan status kewarganegaraan WNI. Sehingga, orang yang berada di luar negeri berasal dari orang tua WNI dapat dikategorikan sebagai WNI. Sementara itu, bagi anak hasil dari perkawinan campuran berhak mempunyai dua kewarganegaraan, sampai anak itu berusia 18 tahun atau sudah menikah, sehingga dapat menentukan sendiri suatu kewarganegaraan yang akan dipilih. Pemberian dua kewarganegaraan dilakukan secara otomatis tanpa dilakukan pendaftaran kepada instansi terkait. Selama penerapan norma itu perlu adanya pengawasan dari pemerintah kepada masing-masing individu. Upaya ini juga merupakan bagian dari kewajiban pemerintah untuk melindungi warga negara.

\section{REFERENSI}

Achmad Edi Subiyanto. (2011). Perlindungan Hak Konstitusional Melalui Pengaduan Konstitusional. Jurnal Konstitusi, Mahkamah Konstitusi RI, 8(5), hlm. 707-732.

Achmadudin Rajab. (2017). Peran Perubahan Undang-Undang Kewarganegaraan dalam Mengakomodir Diaspora untuk Peningkatan Kesejahteraan Masyarakat. Jurnal Konstitusi, Mahkamah Konstitusi RI, 14(3), hlm. 531-530. doi: https://doi. org/10.31078/jk1434

Ady Anugrahadi. (2016, 16 Agustus). 6 Kisah Gloria, Paskibraka yang Gagal Kibarkan Bendera di Istana. Dalam Liputan6.com. Diakses dari https://www.liputan6. com/news/read/2578881/6-kisah-gloria-paskibraka-yang-gagal-kibarkanbendera-di-istana, pada tanggal 23 Juli 2020.

Andi Muhammad Asrun. (2016). Hak Asasi Manusia Dalam Kerangka Negara Hukum: Catatan Perjuangan di Mahkamah Konstitusi. Jurnal Cita Hukum, UIN Syarif Hidayatullah Jakarta, 4(1), hlm. 133-154. doi: https://doi.org/10.15408/jch. v4i1.3200

Chelsea Chesy Bernanda. (2020). Pemberian Kewarganegaraan Indonesia terhadap Archandra Tahar Ditinjau dari Undang-Undang Nomor 12 Tahun 2006 tentang Kewarganegaraan Republik Indonesia. Al Qodiri: Jurnal Pendidikan, Sosial dan Keagamaan, Universitas Surabaya, 18(1), hlm. 199-210.

Donald Kerwin, et al. (2020). Statelessness in the United States: A Study to Estimate and Profile the US Stateless Population. Journal on Migration and Human Security, SAGE journals, 8(2), hlm. 150-213. doi: https://doi. org/10.1177\%2F2331502420907028

Eka Martiana Wulansari. (2015). Konsep Kewarganegaraan Ganda Tidak Terbatas (Dual Nasionality) dalam Sistem Kewarganegaraan di Indonesia. Rechts Vinding Online, Kementerian Hukum dan Hak Azasi Manusia RI, hlm. 1-6.

Haposan Siallagan. (2016). Penerapan Prinsip Negara Hukum di Indonesia. Sosiohumaniora: Jurnal Ilmu-Ilmu Sosial dan Humaniora, Universitas Padjadjaran, 18(2), hlm. 131-137. doi: https://doi.org/10.24198/sosiohumaniora.v18i2.9947 
Jimly Asshiddiqie. (2011, 22-24 November). Gagasan Negara Hukum Indonesia. Makalah dipresentasikan pada Forum Dialog Perencanaan Pembangunan Hukum Nasional, diselenggarakan oleh Badan Pembinaan Hukum Nasional, Kementerian Hukum dan Hak Asasi Manusia Republik Indonesia, di Jakarta.

Laili Fadliyah. (2018). "Analisis Putusan Mahkamah Konstitusi Nomor 80/PUUXIV/2016 tentang Uji Materi Pasal 41 Undang-Undang Nomor 12 Tahun 2006 tentang Kewarganegaraan". Skripsi. Fakultas Syari'ah dan Hukum, Universitas Islam Negeri Sunan Kalijaga, Yogyakarta.

Leonora Bakarbessy \& Sri Handajani. (2012). Kewarganegaraan Ganda Anak dalam Perkawinan Campuran dan Implikasinya dalam Hukum Perdata Internasional. Perspektif: Kajian Masalah Hukum dan Pembangunan, Universitas Wijaya Kusuma Surabaya, 17(1), hlm. 1-9. doi: http://dx.doi.org/10.30742/perspektif.v17i1.89

May Lim Charity. (2016). Urgensi Pengaturan Kewarganegaraan Ganda bagi Diaspora Indonesia. Jurnal Konstitusi, Mahkamah Konstitusi RI, 13(4), hlm. 809-827. doi: https://doi.org/10.31078/jk1346

Miriam Budiardjo. (2002). Dasar-Dasar Ilmu Politik (Edisi Revisi). Jakarta: PT. Gramedia Pustaka Utama.

Peraturan Pemerintah Republik Indonesia Nomor 2 Tahun 2007 tentang Tata Cara Memperoleh, Kehilangan, Pembatalan, dan Memperoleh Kembali Kewarganegaraan Republik Indonesia. (Lembaran Negara Republik Indonesia Tahun 2007 Nomor 2. Tambahan Lembaran Negara Republik Indonesia Nomor 4676).

Rahmawati Novia Sigit. (2020). Perlindungan Terhadap Orang Tanpa Kewarganegaraan (Stateless People) dalam Hukum Internasional (Studi Kasus Etnis Rohingya di Myanmar). Uti Possidetis, Universitas Jambi, 1(1), hlm. 110-138.

Sali Kadria. (2017). A Historical View about Concepts, Theories and Types of Nationalism. Anglisticum, Association-Institute for English Language and American Studies, 6(6), hlm. 23-29.

Undang-Undang Dasar Negara Republik Indonesia Tahun 1945.

Undang-Undang Republik Indonesia Nomor 3 Tahun 1946 tentang Warga Negara dan Penduduk Negara.

Undang-Undang Republik Indonesia Nomor 6 Tahun 1947 tentang Perubahan UndangUndang Nomor 3 Tahun 1946 tentang Warga Negara dan Penduduk Negara.

Undang-Undang Republik Indonesia Nomor 62 Tahun 1958 tentang Kewarganegaraan Republik Indonesia. (Lembaran Negara Republik Indonesia Tahun 1958 Nomor 113. Tambahan Lembaran Negara Republik Indonesia Nomor 1647).

Undang-Undang Republik Indonesia Nomor 3 Tahun 1976 tentang Perubahan Pasal 18 Undang-Undang Nomor 62 Tahun 1958 tentang Kewarganegaraan Republik Indonesia. (Lembaran Negara Republik Indonesia Tahun 1976 Nomor 20. Tambahan Lembaran Negara Republik Indonesia Nomor 3077). 
Undang-Undang Republik Indonesia Nomor 12 Tahun 2006 tentang Kewarganegaraan Republik Indonesia. (Lembaran Negara Republik Indonesia Tahun 2006 Nomor 63. Tambahan Lembaran Negara Republik Indonesia Nomor 4634).

Undang-Undang Republik Indonesia Nomor 6 Tahun 2011 tentang Keimigrasian. (Lembaran Negara Republik Indonesia Tahun 2011 Nomor 52. Tambahan Lembaran Negara Republik Indonesia Nomor 5216).

W.Wahono \& Abdul Atsar.(2019). BukuAjar Pendidikan Pancasila dan Kewarganegaraan. Yogyakarta: Deepublish.

Glery Lazuardi. (2020). Status Kewarganegaraan Ganda Dilihat dari Perspektif Undang-Undang Nomor 12 Tahun 2006 tentang Kewarganegaraan Republik Indonesia. i SIGn Jurnal Hukum, CV. Social Politic Genius (SIGn), 2(1), hlm. 43-54. doi: https://doi. ' I org/10.37276/sjh.v2i1.64 